\title{
Relationship between geologic structure and the source fault of the 2004 Mid-Niigata Prefecture Earthquake, central Japan
}

\author{
Hiroshi Sato and Naoko Kato \\ Earthquake Research Institute, University of Tokyo, 1-1-1 Yayoi, Bunkyo-ku, Tokyo, 113-0032, Japan
}

(Received February 15, 2005; Revised April 20, 2005; Accepted April 21, 2005)

\begin{abstract}
The geologic structure of the Uonuma Hills, the site of the 2004 Mid-Niigata Prefecture Earthquake (M JMA $_{\text {JM }}$ 6.8), Japan, is examined based on published geologic maps, drill hole data and seismic reflection profiles. The Uonuma Hills are located in an active folding area on the eastern margin of the Niigata sedimentary basin, and are divided into three discrete regions from north to south based on the geologic structure. The southern extent is marked by a west-dipping homoclinal structure produced by reverse faulting of the west-dipping Muikamachi active fault. The central section exhibits a regional anticlinorium produced by west-dipping reverse faulting with a steep angle at depth $(>5 \mathrm{~km})$ and a more shallow angle $\left(30^{\circ}\right)$ near the surface. This fault can be correlated with the source fault responsible for the main shock. The Muikamachi fault consists of two fault segments and the source faults of the northern and the southern segments show discrete geometry forming an step over. Thus, judging from the geologic structure, the 2004 Mid-Niigata Prefecture Earthquake ruptured to the maximum possible extent in this fault segment in the central part. Furthermore, this study reveals that the activity on the Muikamachi fault, which has an apparently continuous surface trace, is produced by two different source faults at depth, with important implications for seismic risk assessment.
\end{abstract}

Key words: 2004 Mid-Niigata Prefecture Earthquake, geologic structure, active fold-and-fault, segmentation, balanced cross-section, central Japan.

\section{Introduction}

Seismic hazard assessment of devastative earthquakes in the areas of active folding presents particularly difficult problems, mainly due to the complex relationship between source faults at depth and active faults-and-folds near the surface. The 2004 Mid Niigata Prefecture Earthquake ( M $_{\mathrm{JMA}}$ 6.8) occurred in a convergent folded terrane in central Japan (Fig. 1), and the parameters of the source fault have been well determined by geophysical observations (e.g. Hirata et al., 2005). However, despite the small displacement of this event at the source, surface ruptures associated with this earthquake have been discovered by the Active Fault Research Center of the Agency of Industrial Science and Technology (AIST), Japan along the Muikamachi fault-bounded eastern rim of the Uonuma Hills (e.g. Maruyama et al., 2005). To correlate the source fault and surface ruptures with individual geologic structures is crucial to improving seismic hazard assessments in areas of active folding. To this end, we have examined the surface geology (Yanagisawa et al., 1985; Yanagisawa et al., 1986; Kobayashi et al., 1991), drill holes and seismic reflection profiles (JNOC, 1988; Sato et al., 2005; Kato et al., 2005), and have correlated the source and earthquake faults with the geologic structure. In this paper, this correlation is presented and a segmentation model for the Muikamachi fault is proposed.

Copy right(c) The Society of Geomagnetism and Earth, Planetary and Space Sciences (SGEPSS); The Seismological Society of Japan; The Volcanological Society of Japan; The Geodetic Society of Japan; The Japanese Society for Planetary Sciences; TERRAPUB.

\section{The 2004 Mid-Niigata Prefecture Earthquake and Geologic Background}

The Niigata sedimentary basin was formed as a back-arc rift basin associated with the opening of the Sea of Japan and now presents more than $6 \mathrm{~km}$ of accumulated basin fill in the central part of the basin (eg. Takano, 2002; Niigata Prefectural Government, 2000; Sato, 1994). The thickness of the Neogene sediments in the Niigata sedimentary basin shows it maximum in the circum Sea of Japan region (Tamaki, 1988). Since the late Neogene, the basin suffered WNW-ESE trending contraction, and folds associated with reverse faults have developed throughout this area. As a regional tectonic feature, the damaged area is marked by large zones of convergent deformation along the eastern boundary of the Sea of Japan. The Uonuma Hills, the area damaged by the 2004 Mid-Niigata Prefecture Earthquake, are located on the eastern margin of the sedimentary basin and were formed by this shortening deformation (Fig. 2). The eastern margin of the Niigata sedimentary basin is bounded by the Shibata-Koide tectonic line (SKL; Yamashita, 1970). The southern-most part of the SKL is known as the active Muikamachi fault (Kim, 2004).

The 2004 Mid-Niigata prefecture earthquake occurred at 17:56 (JST) on October 23, 2004 with a local body wave magnitude $\left(\mathrm{M}_{\mathrm{JMA}}\right)$ of 6.8 . The hypocenter was located below the western flank of the Uonuma Hills at a dept of 13 km (Fig. 1; Hirata et al., 2005; Sakai et al., 2005). The main shock was followed by intense aftershock activity, including five major aftershocks of $\mathrm{M}_{\mathrm{JMA}} 5.5$ or greater on the 23rd, and others on the 25th ( $\left.\mathrm{M}_{\mathrm{JMA}} 5.8\right), 27$ th $\left(\mathrm{M}_{\mathrm{JMA}}\right.$ 

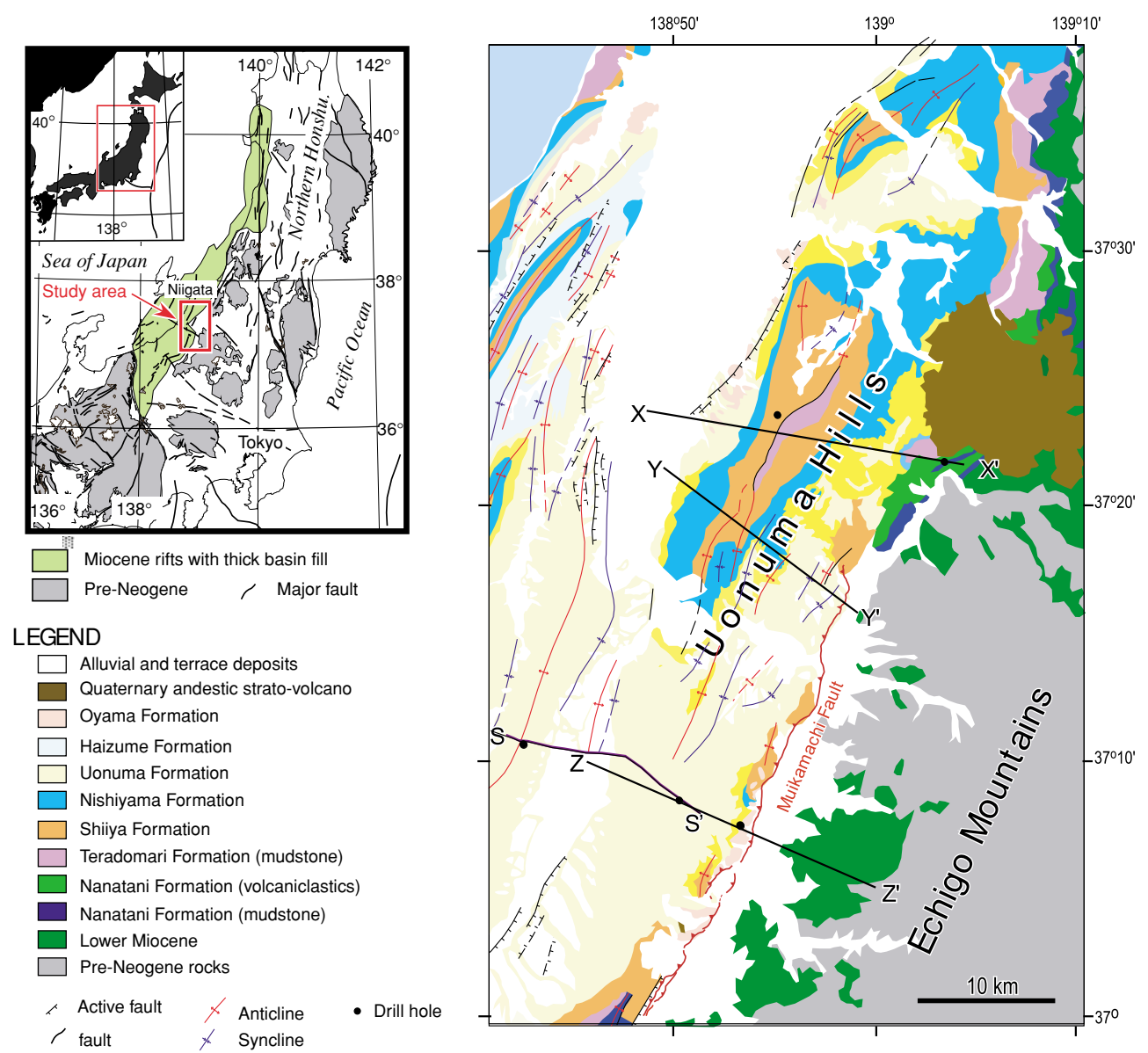

Fig. 1. Geologic map of Mid-Niigata Prefecture, central Japan (Niigata Prefectural Government, 2000). Seismic line S-S' is shown in Fig. 3. X-X', Y- $Y^{\prime}$ and $Z-Z^{\prime}$ correspond to the geologic sections shown in Fig. 4.

6.1) and November 8 ( $\mathrm{M}_{\mathrm{JMA}}$ 5.9). Based on the observation of aftershocks using a temporal seismic array, the geometries of three source faults have been identified for this sequence of events (Hirata et al., 2005). The main shock was generated by reverse slip on a NE-trending fault, dipping $57^{\circ} \mathrm{W}$. The source fault of the largest aftershock $\left(\mathrm{M}_{\mathrm{JMA}} 6.5\right.$ : JST 18:34, October 23) has a NE-trending, west-dipping fault plane. The third of the source faults identified corresponds to the aftershock of October $27\left(\mathrm{M}_{\mathrm{JMA}} 6.5\right.$, JST 18:34), and is located beneath the Echigo Mountains with an east-dipping, low-angle geometry. The direct up-dip extension of the source fault of the largest aftershock corresponds to the Muikamachi fault on the SKL, and surface ruptures associated with the earthquake were discovered along this fault (Maruyama et al., 2005). However, no seismicity was detected in the shallower part of the SKL by aftershock observations. This problem is discussed later.

\section{Geologic Structure of the Uonuma Hills}

Detailed information of the surface geology around the Uonuma Hills has been presented in a series of geologic maps published by the Geological Survey of Japan (Yanagisawa et al., 1985, 1986; Kobayashi et al., 1991). The basic geologic structure of the Uonuma Hills can be seen from the strike-line pattern to be divided into three parts along the strike (southern, central, and northern; Fig. 2). The geologic structure of the southern extent of the Uonuma Hills is char- acterized by a west-dipping homoclinal structure (Yanagisawa et al., 1985). The geologic structure across the western flank of the Uonuma Hills has been determined based on the seismic reflection profile obtained by the Japan National Oil Corporation (JNOC, 1988), as shown in Fig. 3. The west-dipping reflectors in the seismic profile are imaged down to $6 \mathrm{~km}$, supporting the homoclinal structure of the Uonuma Hills. The Uonuma Group shows westward thickening at the western flank of the Uonuma Hills, suggesting the large-scale growth strata by the tectonic movement. The eastern rim of the hills is bounded by the westdipping Muikamachi fault (Kim, 2004), which is also identified as the western Muikamachi basin fault (Suzuki et al., 2001) and the Ishiuchi fault (Kim, 2001). The Muikamachi fault is a west-dipping reverse fault that coincides with the SKL. In fact, according to the Bouguer gravity anomalies (Hiroshima et al., 1994), which revealed lower values approaching the hanging wall of the Muikamachi fault, the hanging wall is overlain by thicker sediment than the footwall. Based on the tectonic geomorphology, the vertical slip rate of the Muikamachi fault is $2 \mathrm{~mm} / \mathrm{year}$, and the asymmetric pattern of uplift of the hills has been well preserved in terms of the westward tilting of river terraces (Kim, 2001, 2004). The reverse faulting of the Muikamachi fault played a major role in the uplift of the Uonuma Hills, and the homoclinal structure of the hills suggests a simple fault geometry at depth (Fig. 4(C)). 


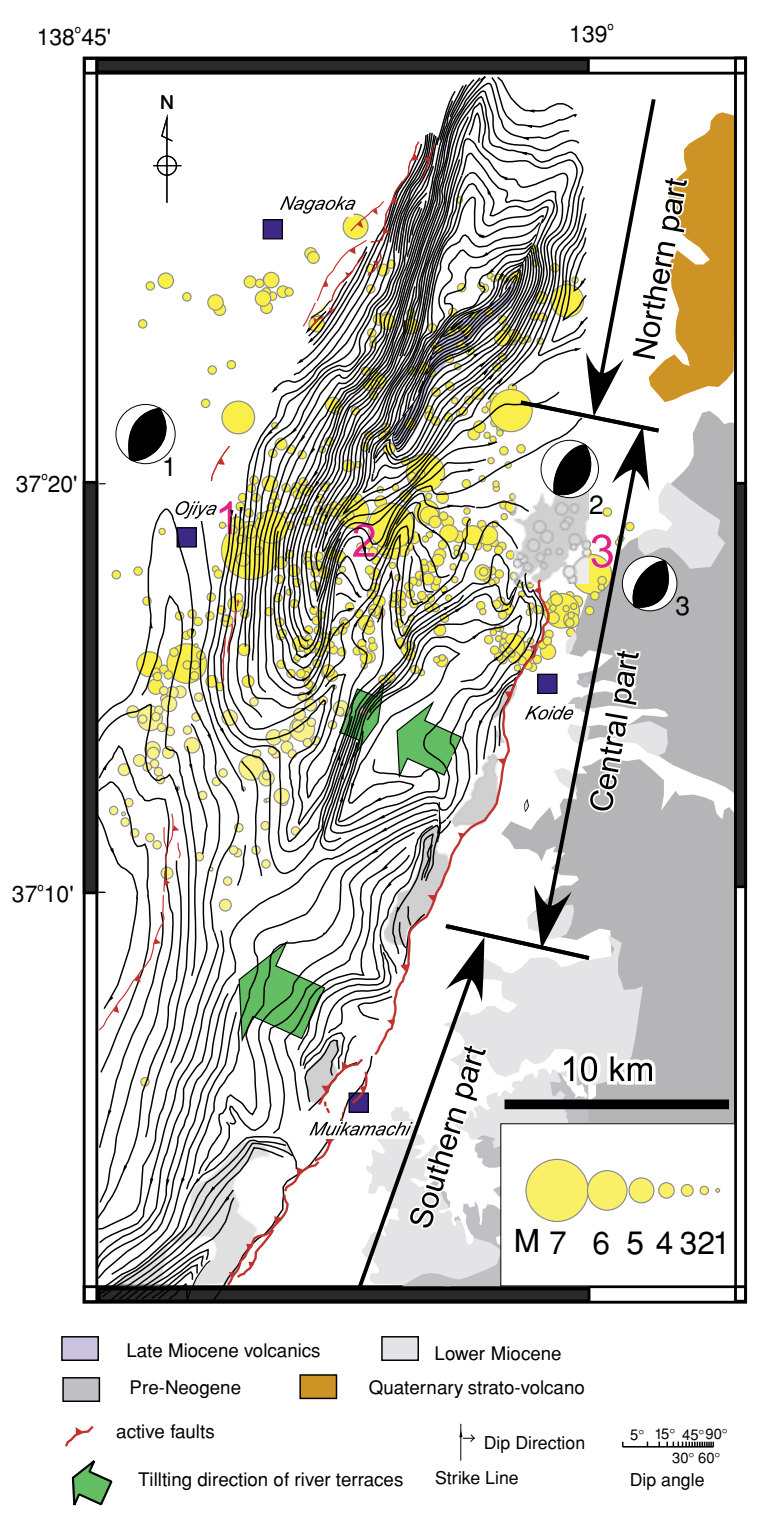

Fig. 2. Strike-line map for Uonuma Hills area showing the distribution of aftershock hypocenters (October 24-27; Hirata et al., 2005), surface geology (Yanagisawa et al., 1985, 1986; Kobayashi et al., 1991), traces of active faults (Watanabe et al., 2001; Tsutsumi et al., 2001; Suzuki et al., 2001) and tilting of river terraces (Kim, 2004). 1: Hypocenter of main shock ( $\mathrm{M}_{\mathrm{JMA}} 6.8$ : JST 17:56, October 23). 2: Hypocenter of

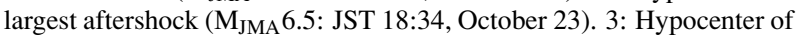
aftershock on October $27\left(\mathrm{M}_{\mathrm{JMA}} 6.5\right.$, JST 18:34). Fault plain solutions are after Sakai et al. (2005).

The geologic structure of the central section of the Uonuma Hills (Fig. 4(B)) is marked by an anticlinorium trending NNE-SSW. The main Higashiyama anticline has a steeply dipping eastern flank. The eastern rim of the central hills region is also bounded by the Muikamachi fault. The vertical slip rate of more northern extent of the Muikamachi fault in this area is $1 \mathrm{~mm} / \mathrm{year}$ (Kim, 2004). The shallow seismic reflection profile portrays the low-angle geometry of the Muikamachi fault (Kato et al., 2005).

The geologic structure of the northern section of the Uonuma Hills is characterized by an anticlinorium trending NNE-SSW. The geologic section based on deep drill holes (Niigata Prefectural Government, 2000) and surface geology (Kobayashi et al., 1991) is shown in Fig. 4(A).

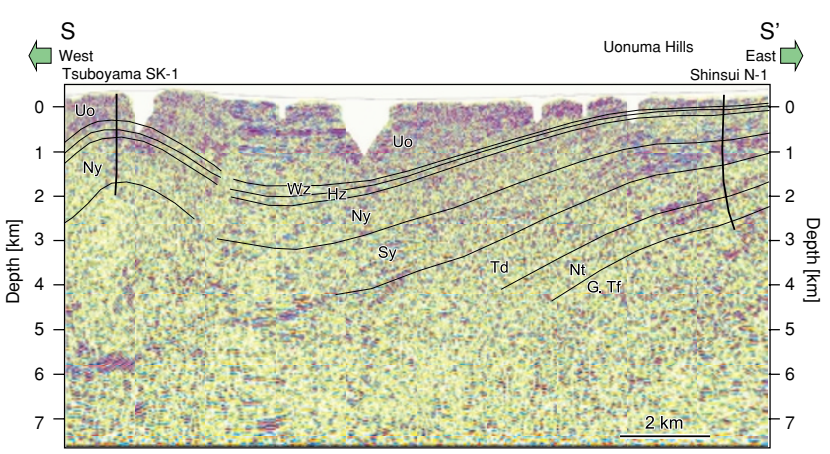

Fig. 3. Post-stack migrated, depth converted seismic section across the western flank of the Uonuma Hills. Depth conversion was carried out by authors using the seismic data of JNOC (1988). The location of seismic line is shown as ${\mathrm{S}-\mathrm{S}^{\prime}}^{\prime}$ in Fig. 1. Seismic source was a series of 12 $\mathrm{kg}$ dynamite explosions at intervals of $40 \mathrm{~m}$, and seismic signals were recorded by 240 channels at $10 \mathrm{~m}$ intervals. Geologic interpretation is based on the drill hole data (JNOC, 1988) and depth converted section. Uo: Uonuma Formation, Wz: Wanazu Formation, Hz: Haizume Formation, Ni: Nishiyama Formation, Sy: Shiiya Formation, Te: Teradomari Formation, Nt: Nanatani Formation, Gt: Green tuff (Lower Miocene volcanics).

The main Higashiyama anticline also exhibits a steeply dipping western flank in this region. This asymmetric geometry of the anticline is suggestive of west-vergent reverse faulting. The east-dipping reverse fault explains the uplift of the eastern side of the faults. The western rim of the hills is bounded by the Yukyuyama fault (Tsutsumi et al., 2001), which is an active east-dipping reverse fault. Judging from the general geologic structure, the east-dipping reverse faults are dominant in the northern section of the Uonuma Hills.

\section{Geometry of Seismogenic Source Faults along the Uonuma Hills}

The southern extent of the hypocentral distribution of aftershocks clearly coincides with the boundary identified by the geologic structure (Fig. 2). The aftershocks are concentrated in the central region, which is characterized by a regional anticlinorium. The two-dimensional model describing the principle geologic structures of the Uonuma Hills shown in Fig. 4(B) was proposed based on the shallow seismic reflection profile across the surface ruptures and the geometry of source faults estimated from the hypocentral distribution of aftershocks (Kato et al., 2005). This geologic structure can be explained by a high-angle fault geometry $\left(60^{\circ}\right)$ at depths of 5-15 km and a low-angle geometry $\left(30^{\circ}\right)$ in the shallower surface. This geometry explains the formation of both the Higashiyama anticline and the Muikamachi fault. In the southern section of the Uonuma Hills, the Muikamachi fault coincides with the SKL. However, despite the surface ruptures along the Muikamachi fault in the central section, no shallow seismicity was recorded in this region of SKL (Hirata et al., 2005). This is consistent with the suggestion that the Muikamachi fault in the central section of the hills was formed by a deep source fault further to the west (Fig. 5). That is, the Muikamachi fault is a manifestation of two source faults. In the southern extent of the fault, the main fault at depth has a simple west-dipping geometry without major bending, as suggested by the homo- 

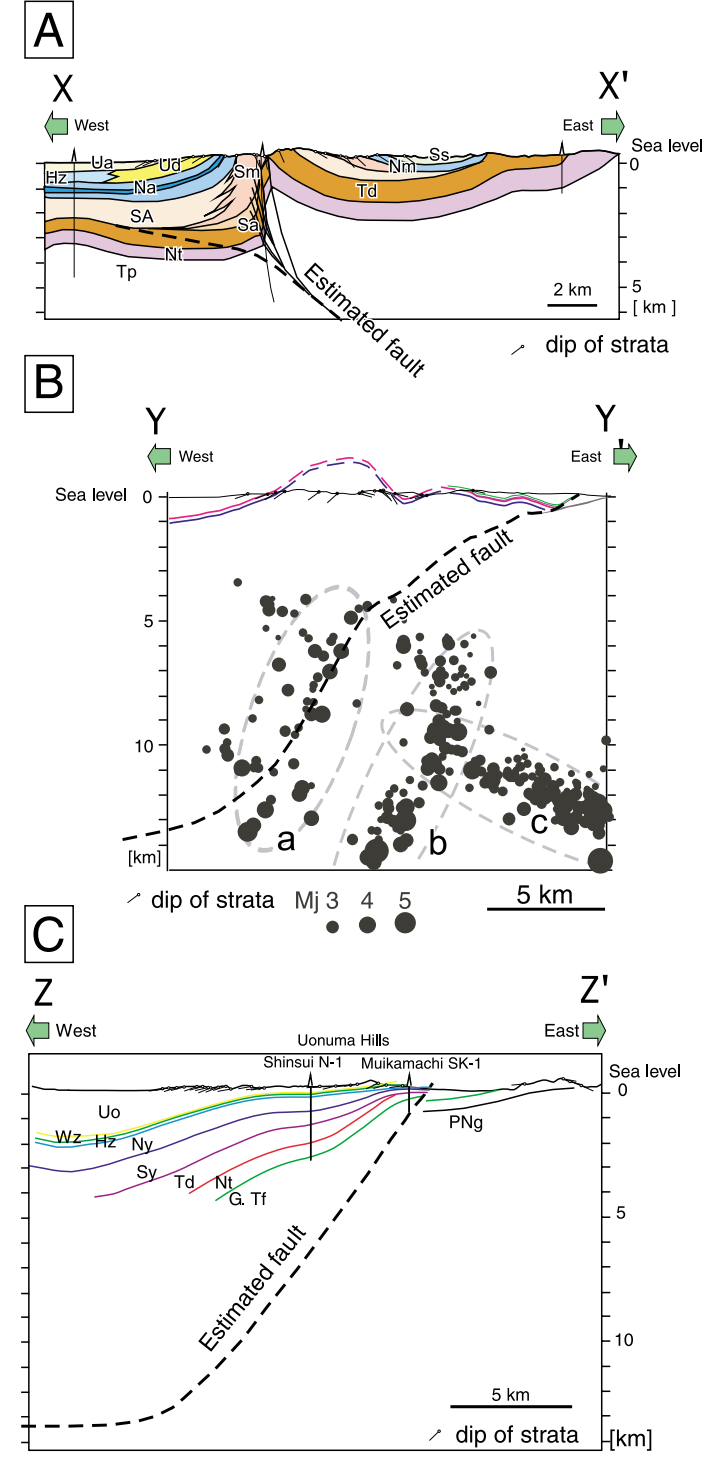

Fig. 4. Geologic cross-sections across the Uonuma Hills (see Fig. 1 for section locations), showing strata dip (Yanagisawa et al., 1985, 1986; Kobayashi et al., 1991), drill core data and interpretations (A: Niigata Prefectural Government, 2000. B: Kato et al., 2005. C: JNOC, 1988). PNg: Pre-Neogene, Tp: lower Miocene and Pre-Neogene, Gt: Green tuff (Lower Miocene volcanics), Nt: Nanatani Formation, Td: Teradomari Formation, Sy: Shiiya Formation, SA: Andesite lava and volcaniclastic sediments of the Shiiya Formation, Sa: Interbedded sandstone and mudstone of the Shiiya Formation, Sm: Mudstone of the Shiiya Formation, Ny: Nishiyama Formation, Nm: Mudstone of the Nishiyama Formation, NA: Andesite lava and volcaniclastic sediments of the Nishiyama Formation, Ss: Shiroiwa Formation, Hz: Haizume Formation, Uo: Uonuma Formation, Ud: Dacite to andesite lava and volcaniclastic sediments of the Uonuma Formation, Ua: Sand, mud and sandy gravel of the Uonuma Formation. The swarms of aftershocks labeled (a), (b) and (c) correspond to the main shock (M $\mathrm{M}_{\mathrm{JMA}} 6.8$ : JST 17:56, October 23), the largest aftershock ( $\mathrm{M}_{\mathrm{JMA}}$ 6.5: JST 18:34, October 23), and the aftershock on October 27 (M $\mathrm{M}_{\mathrm{JMA}} 6.5$, JST 18:34), respectively.

clinal structure of the hanging wall (Fig. 5). In contrast, the deep main fault driving the activity on the northern extent of the Muikamachi fault is located further west and is notably bent at shallower levels (Fig. 5). Thus, the most important observation that can be drawn from the 2004 Mid-Niigata Earthquake is that active faults with an apparently contin-

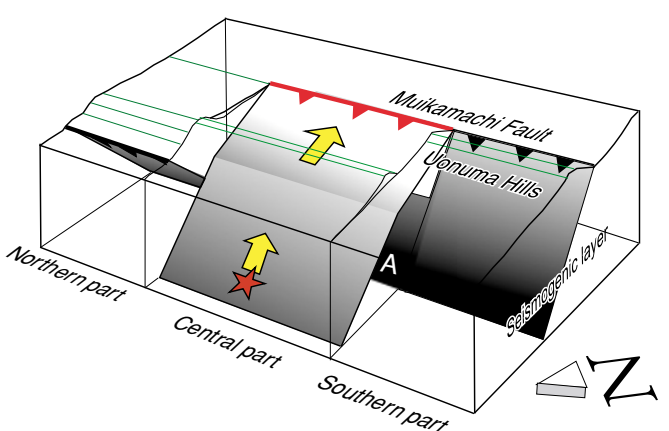

Fig. 5. Schematic diagram showing possible source faults along the Uonuma Hills. Red star represents the hypocenter of the main shock and yellow arrows denote associated coseismic slip. (A) Area ruptured by the largest aftershock ( $\mathrm{M}_{\mathrm{JMA}}$ 6.5: JST 18:34, October 23).

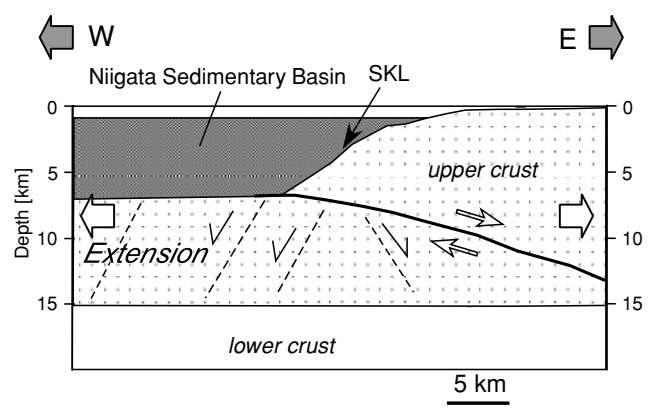

Fig. 6. Schematic diagram showing the fault system during the final stage of the Miocene rifting. Basic concept is after Ikeda et al. (2002).

uous surface trace may in fact have multiple contributing source faults. The key to revealing such cases is to evaluate the geologic structure accommodating active faults and/or folds.

The northern extent of the Uonuma Hills is dominated by geologic structures associated with an east-dipping fault system, which ruptured as part of the aftershock sequence in 2004 (Sakai et al., 2005). The size of the rupture domain appears to be closely related to the geologic structure. Thus, the main shock of the 2004 Mid-Niigata Earthquake appears to have been produced by the maximum extent rupturing of the source fault allowed by the local geologic structure.

\section{Fault Evolution around the Uonuma Hills}

Fault reactivation and basin inversion processes has played important roll on the deformational processes in the continental crust. Reverse faulting on Miocene normal faults produced devastating earthquakes, such as the Northern Miyagi earthquake of 2003 ( $\mathrm{M}_{\mathrm{JMA}}$ 6.4; Kato et al., 2004). The better understanding of fault evolution is significant for precise estimation of the geometry of source faults. The SKL is not a simple Miocene normal fault and but an probable unconformity on the western (basin-ward) flank of a roll-over anticline, which was formed in the hanging wall of a low-angle, east-dipping low-angle normal-fault that was responsible for the rifting of the Niigata basin in Miocene (Ikeda et al., 2002). From the view point of the basin development, the east-dipping, low-angle fault is the most important one for the formation of the basic geologic structure. The source fault of the aftershock on October 
27 ( $\mathrm{M}_{\mathrm{JMA}}$ 6.5, JST 18:34) shows an east-dipping thrust, indicating the existence of previously estimated east-dipping thrust. The high-angle reverse faults, which generated the main-shock and largest aftershock, might be formed as a normal fault in the footwall during the later stage of the Miocene rifting. To construct the realistic model of the fault and basin evolution, including basin evolution, will become an important step for the seismic hazard assessment in the areas of active folding and more precise evaluation of the 2004 Mid-Niigata Prefecture Earthquake.

\section{Conclusions}

Based on the surface geology, drill hole data and seismic profiles, three different styles of deformation are recognized from north to south in the Uonuma Hills. The southern extent is marked by a west-dipping homoclinal structure formed by a west-dipping reverse fault at the eastern edge of the hills. The central and northern sections are marked by a regional anticlinorium, formed in the central section by a west-dipping reverse faulting and in the northern extent by east-dipping reverse faulting. The hypocentral distribution of aftershocks thus indicates that the extent of rupture associated with the 2004 Mid-Niigata Prefecture Earthquake was strongly controlled by the pre-existing geologic structure, and that the maximum extent of rupture allowed by the geologic structure occurred in this event.

Acknowledgments. We thank to Yasutaka Ikeda and an anonymous reviewer for thoughtful comments. The Japan National Oil Cooperation is gratefully acknowledged for seismic profile data, and gratitude is extended to Shin'ichi Sakai for valuable discussion. This research was supported by the Special Coordination Funds for Promoting Science and Technology from the Ministry of Education, Sports, Culture, Science and Technology of Japan.

\section{References}

Hirata, N., H. Sato, S. Sakai, A. Kato, and E. Kurashimo, Fault system of the 2004 Mid Niigata prefecture earthquake and its aftershocks, Landslides, 2(2), doi:10.1007/s10346-005-0050-8, 2005.

Hiroshima, T., M. Komazawa, and T. Nakatsuka, Gravity map of Hoshinetsu district (Bouguer anomalies), Gravity map series 5, Geol. Surv. Japan, 1994.

Ikeda, Y., T. Imaizumi, M. Togo, K. Hirakawa, T. Miyauchi, and H. Sato, Atlas of Quaternary thrust faults, Tokyo Univ. Press, 254 p, 2002.

JNOC, Report on basic geophysical exploration in onshore area "KubikiTamugiyama”, Japan National Oil Corporation, Tokyo, 45 pp., 1988 (in Japanese).

Kato, N., H. Sato, T. Imaizumi, Y. Ikeda, S. Okada, K. Kagohara, T. Kawanaka, and K. Kasahara, Seismic reflection profiling across the source fault of the 2003 Northern Miyagi earthquake (Mj 6.4), NE Japan: basin inversion of Miocene back-arc rift, Earth Planets Space, 56, 1255-1261, 2004.

Kato, N., T. Echigo, H. Sato, M. Tateishi, S. Ogino, S. Sakai, S. Toda, S. Koshiya, T. Ito, T. Toyoshima, T. Imaizumi, H. Kato, and S. Abe, Geologic fault model based on the high-resolution seismic reflection profile and aftershock distribution associated with the 2004 Mid-Niigata Prefecture earthquake (M6.8), central Japan, Earth Planets Space, 57, this issue, 447-452, 2005.

Kim, H. Y., Relationship between the upheaval process of the Uonuma Hills and cumulative nature of the Muikamachi fault, central Japan, Active Fault Research, 24, 63-75, 2004 (in Japanese with English abstract).

Kim, H. Y., Active faults along the western margin of the Muikamachi basin, central Japan, The Quaternary Res., 40, 161-168, 2001 (in Japanese with English abstract).

Kobayashi, I., M. Tateishi, T. Yoshioka, and M. Shimazu, Geology of the Nagaoka district, with Geological Sheet Map at 1:50,000, Geological Survey of Japan, 132 pp., 1991 (in Japanese with English abstract).

Maruyama, T., Y. Fusejima, T. Yoshioka, and Y. Awata, Morphological characteristics of the surface rupture associated with the $2004 \mathrm{Mid}$ Niigata Prefecture earthquake in 2004, Chishitsu News, 607, 13-17, 2005 (in Japanese).

Niigata Prefectural Government, Geology of the Niigata prefecture, with Geological Sheet Map at 1:200,000, Niigata Prefectural Government, 200 pp., 2000 (in Japanese).

Sakai, S., N. Hirata, A. Kato, E. Kurashimo, T. Iwasaki, and T. Kanazawa, Multi-fault system of the 2004 Mid-Niigata Prefecture Earthquake and its aftershocks, Earth Planets Space, 57, this issue, 417-422, 2005.

Sato, H., The relationship between late Cenozoic tectonic events and stress field and basin development in northeast Japan, J. Geophys. Res., 99, 22261-22274, 1994.

Sato H., N. Kato, T. Echigo, S. Ogino, M. Tateishi, S. Toda, H. Kato, S. Koshiya, T. Toyoshima, T. Ito, T. Imaizumi, S. Abe, N. Suzuki, E. Misawa, S. Oda, K. Kagohara, T. Koike, S. Akai, and K. Noda, High resolution seismic reflection profiling across the surface rupture associated with the 2004 Mid-Niigata Prefecture earthquake, central Japan: data acquisition and processing, Bull. Earthq. Res. Inst., 2005 (submitted) (in Japanese with English abstract).

Suzuki, Y., M. Togo, M. Watanabe, Y. Kim, and N. Sato, Active fault map in urban area: Tokamachi, Technical report of the Geographical Survey Institute, D.1, No. 388, 2001.

Takano, O., Changes in depositional systems and sequences in response to basin evolution in a rifted and inverted basin: an example from the Neogene Niigata-Shin'etsu basin, Northern Fossa Magna, central Japan, Sedimentary Geology, 152, 79-97, 2002.

Tamaki, K., Geologic structure of the Japan Sea and its tectonic implication, Bull. Geol. Surv. Japan, 39, 269-365, 1988.

Tsutsumi, H., M. Togo, M. Watanabe, Y. Kim, and N. Sato, Active fault map in urban area: Nagaoka, Technical report of the Geographical Survey Institute, D.1, No. 388, 2001.

Watanabe, M., H. Tsutsumi, Y. Suzuki, H. Y. Kim, and N. Sato, Active fault map in urban area: Ojiya, Technical report of the Geographical Survey Institute, D.1, No. 388, 2001.

Yamashita, N., Proposal of the Choshi-Kashiwazaki tectonic line, in The Island Arc and Ocean, edited by T. Hoshino and T. Aoki, Tokai Univ. press, pp. 179-191, 1970 (in Japanese).

Yanagisawa, Y., K. Chihara, Y. Suzuki, T. Uemura, K. Kodama, and T. Kato, Geology of the Tokamachi district, with Geological Sheet Map at 1:50,000, Geological Survey of Japan, 104 pp., 1985 (in Japanese with English abstract).

Yanagisawa, Y., I. Kobayashi, K. Takeuchi, M. Tateishi, K. Chihara, and T. Kato, Geology of the Ojiya district, with Geological Sheet Map at 1:50,000, Geological Survey of Japan, 177 pp., 1986 (in Japanese with English abstract).

H. Sato (e-mail: satow@eri.u-tokyo.ac.jp) and N. Kato 